\title{
A SURVEY OF FAMILY TRANSFORMATIONS IN BOSNIA AND HERZEGOVINA
}

\author{
Selvira Draganovic \\ International University of Sarajevo
}

\begin{abstract}
Globalization has strong impact on individuals and societies at large and family as most the most essential and fundamental cell in society is no exception. Nowadays, family has lost some of its basic internal functions whilst widespread and all present technological aids, strong needs for independence and individualism furthermore contribute to estrangement of and family members' alienation. At the same time, status and roles of family members within family are changing as well. Despite these global trends and changes, family continues to be considered the most essential and supremely significant social institution, which gratifies and serves many individual and collective functions. This paper surveys family systems and transformations in Bosnia and Herzegovina, especially post-war and contemporary family developments.
\end{abstract}

Keywords: BiH; Family; Counseling and Psychotherapy; Family Transformations; Post-War Family.

\section{Introduction}

Family has always been a subject of interest of social as well as natural sciences. In its essence and nature, family consists of individuals whose genetic and psychological makeup influences its existence, functioning and internal dynamics. Family itself, alongside those composing it, creates larger social picture and society in general, and both are subject to numerous trends and changes. Diverse local, individual and global trends and changes affect family and its members in a different way whereas unhealthy (dysfunctional) families tend to be less resilient and less able to resist them. Healthy family, on the other hand, succeeds to fully fulfill its basic functions, creates the best conditions for growth and maturity, self assertion and self expression for its members and has clear norms for internal and intra-familial roles (Sedrakyan, 2014). Thus, healthy family tends to be more resilient and serves as foundation for a healthy and strong society. 
Family members constitute society members. Good/healthy family (healthy familial relations) contributes to stable and healthy society. Healthy relationships lead to better life (life quality). Healthy relationships (including familial relationships) are a vital component of health and wellbeing and great source of support. The research indicates compelling evidence that strong and healthy relationships contribute to a long, healthy, and happy life. On the contrary, the health risks from being alone or isolated in one's life are comparable to the risks associated with cigarette smoking, blood pressure, and obesity whilst having no or low social support is linked to a number of health consequences, such as depression, decreased immune function, higher blood pressure (Holt-Lustand et. al, 2010). The term social support often appears in discussions of relationship and means having friends and other people, including family, to turn to in times of need or crisis to give a broader focus and positive self-image. Thus, good and healthy family relations and social support enhance quality of life and provide a defense against adverse life events.

Latest developments and variations related to family life in a form of cohabitation, communes, single family units, increased divorce rate, new marriage, single parenthood, joint custody of children, families without children, abortions and families with spouses who have two careers (Jagger and Wright, 1999) have jeopardized family and given her a completely new shape. Some researchers are warning that family is in danger or is threatened to completely extinct (Marsh et. all., 2006). Despite this, as old and current research on family shows, all societies have some form of family and marital contracts. Hence, we can say that family remains to be universal institution with great likelihood to prevail but its form can be a subject of great variations.

Scientists of different backgrounds not only apply diverse approaches in family study but also define family differently. Sociologists, as scientists most closely related to family by its simplest definition, traditionally view family as a social group whose members are related by ancestors, marriage or adoption, live together and economically collaborate (Murdock, 1949, in Marsh et all. 2006). Psychologists, on the other hand, being those who are more related to inner psychic states and condition maintain that, it is psychological bond and intimacy per se that what makes a family. Focusing more on psychological concepts, psychologists study family as intimately interrelated group in which members take care of one another, respect one another (Lauer and Lauer, 2000, in Hughes and Kroehler, 2012) and help each other to satisfy and 
fulfill basic physical as well as emotional needs. Satisfaction of basic emotional needs, attachment, bonding and care are core concepts in psychological investigation and study of family and familial relations. Besides, family plays very important role in establishing of personal identity of an adult and his/her roles whereas family gives framework for realizing personal safety, stability, aim towards objectives, purpose, success, self actualization, realization of self values and intimacy (Čudina - Obradović and Obradovic, 2006). These needs and functions are still best served and fulfilled by and within family.

\section{The Conception of Family in Bosnia and Herzegovina}

Considering cultural and historic specificity of Bosnian society, socio-political and psychological impact of recent war, current socioeconomic and political conditions, high divorce and low marriage rates (FZZS, 2014), as well as impact of other, global changes and forces currently characterizing Bosnian society, $\mathrm{BiH}$ family battles a number of challenges. Demography numbers indicate that current Bosnian society is characterized by increased mortality and decreased birth rate during the past decades (FZZS, 2014) and aging population. According to some estimates, $\mathrm{BiH}$ will soon become a country of old people due to the ageing of population (Pejanovic, 2005).

At the same time, although $\mathrm{BiH}$ has been affected by global positive changes and developments, it still belongs to a very traditional society with deeply and strongly rooted patriarchal ideology. Global socio-economic changes which have left some impact on $\mathrm{BiH}$ society as well, indicate presence of conflict between individualistic and traditional values leading to weakening of traditionalism and patriarchy, women empowerment and presence at the labor market, women becoming more independent (Draganovic, 2015). This also indicates presence of significant role restructuring within family (man are no longer sole breadwinners, women, on the top of being mothers and wives have become employees as well etc).

Attention and research interest of local scientists studying family and family relations during the past two decades was mostly directed towards children and youth, violence and/or war trauma (Beridan, 1997; Haverić, 2000; Pašalić-Kreso, 2004; Letić i Ivanović, 2012, Babović i saradnici, 2013; Alić, 2008). Only a few focused their investigation on family (Pašalić-Kreso, 2004), or namely divorce, (Silajdžić, 1973; Begović, 2007; Habul, 2000, Draganovic, 2015). 
In view of family having the most vital role in individual and societal wellbeing and functioning, we ought to point to its possible threats and challenges. Healthy and good functioning society has strong, stable and healthy family and vice versa. Bearing in mind the aforementioned current issues and factors in $\mathrm{BiH}$ society, its most crucial unit, family, faces a number of important challenges. Taking into consideration that families constitute society, applying rather old fashioned approach we will start with discussing general societal challenges (transition of $\mathrm{BiH}$ society) which we further explain by $\mathrm{BiH}$ family transformation and finally ending in discussing more specific personal or individual (psychological in nature) challenges of contemporary living style in $\mathrm{BiH}$.

Serious society's shifts in $\mathrm{BiH}$ began during the socialism times as a result of radically changed social structure, speedy industrialization of the country, mass movements of its citizens in direction village-towns, weakening of patriarchal family and patriarchal moral. At the same time, the state in its constitution proclaimed equality, what enabled larger number of women to educate and get employment. Strong social and political turmoil during the early nineties resulted in transitional processes.

However, besides this regular transition of Bosnian society we also need to discuss psychological transition of $\mathrm{BiH}$ and its citizens which encompass transition of conscience, attitudes and behavior. Many Bosnians who experienced the life in socialist system often talk about it with nostalgia disregarding and forgetting negative sides of it. This nostalgia usually results in psychological impairment or behavior nostalgia which, in psychological terminology described, indicates presence of defense mechanism in a form of denial (denying reality). This is closely related to serious issues related to personal and social identity, inability to healthy adjust to the new system and inability to prosper and move further.

A number of parallel processes characteristic to countries in transition are still going on in $\mathrm{BiH}$. Firstly, $\mathrm{BiH}$ society is still exposed to a number of external forces ( $\mathrm{BiH}$ strives towards European Union membership, EU conditions and pressures $\mathrm{BiH}$ towards socio-economic development and progress) and influences and internal changes which shape up its value system (with declaration of its independence from ex Yugoslavia in 1992 $\mathrm{BiH}$ changed from socialist into democratic society). These processes and changes have direct and/or indirect impact on family system.

As a part of larger social context, family and its system and structure are also exposed to these processes indicating family transformation from 
traditional (very patriarchal) into modern (more democratic). However, traditional power relations and social and cultural roles in family and norms in society were strongly reinforced during former Yugoslav wars whereas gender identities/roles were extremely polarized with men being perceived as warriors and women as mothers and victims (Isanovic, 2006). As Kuburic (2001) states, for centuries, mothers subconsciously, intuitively raise their sons for male dominance (p. 186) paving the way for patriarchal ideology. Considering this, we may state that $\mathrm{BiH}$ society is still characterized by strongly and deeply rooted patriarchal values and attitudes indicating presence of patriarchal family type/form.

\section{The Family Transformations in Bosnia and Herzegovina}

Contemporary $\mathrm{BiH}$ family is patriarchal in nature. Patriarchal type of family organization, as noted by Kosović (1987) is characterized by economic function of family as basic manufacturing unit with strong and clear work division and emphasized hierarchal organization in which the oldest male person was in extremely privileged position in relation to other family members. Hierarchal structure is shaped by important biologically determined criteria, gender, age, whilst men is considered more superior being and the authority of the eldest member was inviolable. Women in patriarchal family had the lowest rank which implied performing hardest jobs (and their work and contribution is frequently undermined or unrecognized). In addition, position of a woman in patriarchal family has been made more difficult by numerous births and the fact that she was economically dependent on others as well. Patriarchal family in which a number of generations live together Considering different position and roles within $\mathrm{BiH}$ patriarchal family two struggles happen. On one side there are those who want to get rid of patriarchy and traditionalism whilst, at the same time, there are those wanting to preserve the myth of patriarchal $\mathrm{BiH}$ family, creating intra and extra familial conflict for a number of reasons.

Preserving the myth of patriarchal (multi generational family) in fact neglects numerous difficulties faced by $\mathrm{BiH}$ family which are linked to economic and social conditions and current position of women/ mother in family system. Recent war with its impact created unique socio-economic conditions (unemployment rate in $\mathrm{BiH}$ is $48 \%, \mathrm{BiH}$ has significant number of orphans, incomplete families (partially due to the war/loses and partly due to divorce), in $\mathrm{BiH}$ which brought up 
many changes on individual and societal level. These specific socioeconomic conditions influenced the change of family structure, family relations and family functions. Many $\mathrm{BiH}$ families (war veterans, single parents, unemployed and internally displaced for example) fail to fulfill one of its basic internal functions, the economic function. With the loss of economic function of family social position of family also changes. Family is very important for personal functioning and wellbeing of an individual family members and society in general. When families' foremost economic function and significance is considerably decreased family cohesion is at stake what leads to the increased level of individualization of family members which in turn may result in complex family dynamics and family relations (multiple or polyvalent roles...) This may result in intra-familial conflicts (those advocating traditionalists and democratic ideology, generational gap, misunderstanding between generations) and the lack of its resolution.

$\mathrm{BiH}$ is also characterized by the myth of contemporary (democratic) family in which women's employment contributes to the change of family organization and roles within family or intra-familial roles and statuses. Contemporary or modern family is characterized by changes in family form. Unlike traditional family where more family members (even generations) live under the same roof, contemporary family consists of small number of family members (nuclear family consisting mostly of parents and children (Sedrakyan, 2014). One of the main characteristics of modern family is egalitarian family roles of spouses based on equality and justice. Thus, democratic family form contributes to the quality of family relations in general.

At the sametime, the authorityof a husband and fatherhassignificantly decreased in contemporary (democratic) family form whereas the main mechanism of interaction between parents and children or "interacting pipes" happens two ways: a) father affects children through the mother and, b) mother affects children through father (Sedrakyan, 2014). This shapes family structure and roles and the way of distribution of intrafamilial responsibilities. Women's emancipation by which she gets certain freedom and responsibility coming from it contributes to the increase of individualism, what changes familial relations overall.

Contemporary $\mathrm{BiH}$ family still holds the elements of traditional patriarchal family characterized by strong family morality what makes its structure less strong. Traditional family morality can be so strong that its traces can be seen even in people who are genuine holders of new, 
more humane understanding of family life and living (Dizdarević, 2002) hence strongly influencing family dynamics and relations (often causing conflict between traditionalists and modernist). Traditionalists tend to maintain lifestyle and social roles characteristic to previous generation (insisting on reputation of fathers and grandfathers, implementation of strict negative sanctions). Traditional values in modern (nuclear) families have been greatly lost. Modern families mainly focus on personal abilities and realization of personal goals and motivation to act independently (Sedrakyan, 2014).

In spite of these changes women still hold roles of mothers and wives. This puts women in a position of still performing the key roles in family. Observed from larger perspective, position of $\mathrm{BiH}$ women within larger social context cannot be considered equal. The reasons for this may partly be due to the strongly rooted patriarchal ideology in $\mathrm{BiH}$ society and partly due to the current socio-economic and political conditions in $\mathrm{BiH}$ (women's polyvalent/multiple roles to name at least one).

Family transformation changes may be the sources of conflicts based on family roles and structures within contemporary (modern) $\mathrm{BiH}$ family (mostly conflicts between spouses). Conflict between spouses which have been made even more complex by differences in intellectual and educational levels, personality/character and sexual incompatibilities, material difficulties as well as different value systems shaped by attitudes, forms and culture of family of origin and parenting issues. Parenting issues occur due to the loss of parents' authority on one hand and parental neglecting children's need for independence on the other, as well as parental busyness with work and occupational tasks (both parents have to work long hours to provide for basic family needs, a problem more evident and present in societies with low socioeconomic status like Bosnia) what leaves children unattended, left to themselves, the street, media or peer influence (Ziga, 2012).

Family system is inevitable continuously exposed to numerous social and intra-familial changes which are unstoppable and necessary. Multitude and vehemence of these changes demand socio- psychological adjustment of family and its members and, at the same time, are great sources of individual, familial and societal stress which, in a different way, influence family system and structure and society in general (destabilizing them). This indicates the need and inevitability of social phenomenon in a form of family socio-psychological transformation. As stated by Dizdarevic (2002), no other social phenomenon, „demands 
such subtlety and sensibility as the process of socio psychological transformation of family“ (p. 82.). Youth have a special role in this process (Dizdarević, 1978), whereby they should also show care and critical and constructive attitude in this process. Non critical acceptance of sudden changes which diffract over the borders of family system makes creation of family identity more difficult and represents the challenge to the family existence and intra-familial functions and roles.

Socio-psychological transformation of family in $\mathrm{BiH}$ society is linked to the current social and economic changes in our area which have been intensified in war and post war period. War losses and sufferings and post war difficulties like exile, displacement, problems of return to pre-war homes and problems of co-existence, mass privatization of economy formerly owned by the state, growing unemployment, impacts of war traumas, growing number of suicide and violent and delinquent behavior, emigration, decline in natural population growth are only a few contemporary and current issues of $\mathrm{BiH}$ society today.

Taking into account that family is an assumption of existence of each and every individual, the foundation of socialization and prerequisite to mental health of an individual its survival is vital to healthy society. Strong impacts of above enlisted issues in $\mathrm{BiH}$ society shook or have destroyed previous stability of our family (Beridan, 1997, Pašalić-Kreso, 2004). Destruction of BiH family as a result of war can be seen in number of families in which the mother is sole provider and breadwinner. Compared to the pre war condition, the number of single parents in Federation of $\mathrm{BiH}$ only currently has increased thirteen times, the number of families without fathers also increased ten times and families without mothers also increased 2, 5 times, and almost 3000 children live without both parents, (Pašalić-Kreso, 2004).

At the same time, poverty is currently the most striking characteristic of $\mathrm{BiH}$ society which most directly affects families. Over $30 \%$ of families live in extreme poverty and $50 \%$ of them have monthly income below existential minimum (Pašalić-Kreso, 2004). Insufficient, or even complete lack of support from the state institutions to these families and large unemployment rate (unemployment rate according to some estimates is $48 \%$, FZZS, 2014) further complicates conditions in $\mathrm{BiH}$ society especially in incomplete families and/or single parent families). Today's parents in Bosnia, mothers especially, participate more in so called "grey economy" in order to increase family income and more and more children are left to themselves. 
Inevitable changes brought by aforementioned conditions contribute to prevalence of damaged family relations and unacceptable behavior like violence, delinquency and criminal. Damaged family relations in $\mathrm{BiH}$ families further might be contributing factors in delinquent and criminal acts, criminal relapse and family violence. Besides, immediate war impacts and other changes during the last decades resulted in increased number of young boys who discontinued schooling (usually unemployed or do very low paid jobs) and who have difficulties to form a marriage because they cannot provide the basic conditions for it (Pašalić-Kreso, 2004). Also, birth rate and natural population growth in the past decade also significantly decreased. Due to the decrease of natural population growth (negative rate lasts longer) more people die than there are born citizens in $\mathrm{BiH}$ in post war period. Due to that and to the economic necessity, looking for employment in developed countries of Europe, Bosnia and Herzegovina since the year 2000 became the country with intensive depopulation (Pejanović, 2005). In addition, the long term impacts of recent war in $\mathrm{BiH}$ continue to influence and shape our society and family structure and roles in particular (reflected in number of physical and mental health diseases, incomplete families (without one parent due to war or divorce), second marriages (stepchildren, stepsiblings etc.), internally and externally forcedly displaced family members (Diaspora).

Pašalić Kreso (2004) with her research entitled „changes in my family in the past 5-10 years"discovered that recent war still takes striking place in her students' answers. Thus, we may conclude that there are still traumatic impacts of war and post war experiences of $\mathrm{BiH}$ citizens on family and its members. Exposure of an individual to traumatic events may result in impaired mental health but those impacts might get mitigated and alleviated if relationships within family are good. However, considering current socio-psychological conditions of $\mathrm{BiH}$ citizens (personal traumas, PTSD, not seeking help, displaced /separated family members (living in different countries even continents, meeting with family members annually or once in two years) that many parents and youth experienced numerous and multiple traumas, the trust in many families has been impaired. Due to own (unresolved and untreated) personal traumas, family members may be are focused on own pain and suffering.

Personal trauma could be a challenge, enough by itself, to shake not only stability of BiH family but also its member's mental/psychological state. 
Professionals from the field of psychological services and mental health (psychotherapists) often speak of trauma transmission from generation to generation (trans-generational trauma), which they notice and observe in their professional work of dealing with clients, indicating seriousness of this issue. The crisis of paternal (parental function) due to the personal trauma is contemporary challenge Bosnian family members must learn to deal with. Although transmission of memories in the post-war context of Bosnia and Herzegovina as suggested by Jordanova (2012) is not a clear-cut process, still one may notice its presence in $\mathrm{BiH}$ society in terms of fragmentation of history, handicapped sense of selfhood and belonging in children and a crisis of the paternal function in the family (Jordanova, 2012) and impaired personal skills, indicating personal challenge of family members.

\section{Post-War Family in Bosnia and Herzegovina}

Transition, war, post war period in $\mathrm{BiH}$ (marked by huge socio political issues even twenty years after the war), present serious long term stressors that might have made many Bosnians permanently vulnerable. Many Bosnian families are incomplete (due to loss in war, divorce, some separated during and after the war (half of $\mathrm{BiH}$ population now lives in Diaspora all over the world). Living in Bosnia in current socio-political conditions is very demanding (many families live below poverty line, many elderly and young people are unemployed, with and without degrees), health insurance is free but medical treatments are very expensive (number of serious physical illnesses not possible to treat within $\mathrm{BiH}$ health care system so citizens seek help elsewhere, forced to appeal to the public to collect and raise money), complex administration (getting anything done requires hours of going from institution to institution, place to place (absence from work)...

Nine-years primary school system with very demanding school plan and program which children frequently cannot answer to on their own and parents must step in to help children finish many projects. Instead of spending quality family time relaxing, family time has become job/task oriented, presenting pressure (even conflict) to children and parents. Intra-familial relations (between parents and children) are polarized whereas family members struggle to fulfill their roles, each struggle uniquely on their own what in turn influences the quality of their relations. 
At the same time, vulnerability due to being affected by severe trauma (recent war in $\mathrm{BiH}$ ) or not being resilient or not having learned the skills to cope generally, present great psychological wound which might impair one's ability to cope with current threats and demands of life. Recent research shows that young Bosnians perceive recent war to be one of the biggest changes in their family life (Pasalic-Kreso, 2004). One has to remember that the youth in this research became adults (most probably formed own families by now) and if they did not seek help or learned how to deal with their vulnerabilities, they pass it on to own children (permanent psychological wound and trans-generational trauma).

Having psychological wounds requires specific skills to cope with ordinary demands of daily life and stresses and multiple roles within family and society. Lack of psychological skills (in individuals) and lack of public awareness and systematic strategies to help the needy negatively influence family life. Due to this, family members might be lacking psychological maturity and responsibility (due to wrong role models or unavailability of good role models). Avoiding personal responsibility (pointing fingers to "others", schools, law enforcement forces, judicial system), finding guilt for individual and societal violence, aggression, bullying, delinquency problems (forgetting personal role and contribution to problems), might be due to this psychological vulnerability. Many current $\mathrm{BiH}$ families and members grew and developed under severe traumatic conditions (war, displacement, refugee, camps, parental loss, and family separation), what has influenced their physical and psychological growth (forming and deforming their personality). All these factors influence family members, their ability to function within family, perform their roles and deal with family conflict. Family conflicts are inevitable and require skills to overcome and deal with them successfully otherwise family crisis occurs which erodes family (preventing family to perform its basic function) which negatively reflect in society as well. Family conflicts are sometimes caused by contemporary living style.

Current picture indicate that structure of many $\mathrm{BiH}$ families has eroded (number of single parents with single mothers increased due to war losses and or death of a spouse, divorce etc). Many lack healthy family models (more and more incomplete families), lack of healthy familial relations, roles within family changed (more mothers employed 
and fathers unemployed), parents are busy earning for family, children are left alone, many parents in complete families have multiple roles to perform (indicating great sources of stress).

At the same time, focus on materialism (acquisition of wealth), individualism and individual wishes (egoism and egocentrism, personal happiness) might be sources of conflict within and between family members (pressured to succeed, parents at work and professionally, children at school, children demanding to have a lot of material goods, parents to provide them). Family is most important social and very important psychological institution in which many psycho-emotional and physiological needs should be satisfied. Considering that most people have and or are part of a family, thus have some kind of relations with other, psychological importance of family lies in the fact that good family and intra familial relation serve as a foundation of good or ill wellbeing (mental health) and is a great source of social support whilst, social alienation (Old and Schwartz, 2010) is an inevitable result of contemporary society's preoccupation with materialism and frantic "busyness" indicating that lack of relationships can cause multiple problems with physical, emotional, and spiritual health.

Young people in Bosnia though, for example, perceive less parental support and report having difficulties in family relations (Haverić, 2000). All these are indicators of impaired and eroded mental health of $\mathrm{BiH}$ family members and its functions (contact and communication is very important intra-familial function and seems to be lacking in our society). As a result, another important internal function is endangered: ensuring social-psychological conditions necessary for development and maturation, which might also be lacking in families with unresolved mental health conditions, which in turn might be sources of conflicts between family members. So, family might be the source of stress and conflict instead of being a place of conflict resolution.

End result of this conflict might be impairment or erosion of other internal family functions, namely socialization and emotionalidentification. Impairment and or „erosion „of socialization-education and emotional-identification function of family is a result of current developments in contemporary $\mathrm{BiH}$ society because society is not ready to overtake that. Personality socialization, shaping the value system of children, economic and social care, as Žiga (2012) states, used to be „family concern“ and no longer is. 
In view of all the aforementioned we can say that $\mathrm{BiH}$ family is still in the process of transition from traditional to contemporary (with deeply rooted patriarchal ideology). Father is no longer the sole breadwinner and women, with their employment, have spread their primary roles of being wives, mothers and housewives and have also become significant holders of economic stability of a family. This calls for family duty and responsibility redistribution and obligations of a married couple.

We may notice that expectations of a man and women related to the family gradually started to change which used to be shaped by traditional (patriarchal) models on family functioning brought from family of origin. Thus, a woman wants to be equal which is in accordance with her contribution to family whilst a man wants to maintain his position of authority (due to strong patriarchal tradition). These changes might be the sources of internal stress and strong drivers and organizes of family dynamics which all have been additionally complicated by numerous losses, family separation, war wounds (physical and psychological) and other war and post war traumas and other aftermaths and events in Bosnian and Herzegovina which results in changes of family structure and roles within families.

Although some show psychological resistance (mainly those who had more power and say in traditional families or those with such unconscious family model) to the change of $\mathrm{BiH}$ family type from traditional (patriarchal) into contemporary (democratic), this change is unstoppable and should be approached in a way which firstly addresses this psychological resistance coming from within family (from highly positioned family members). Because, prerequisite for overcoming this psychological resistance is to acknowledge and identify its nature (Dizdarević, 2002), only then it can be appropriately addressed and resolved. Besides, the presence of other numerous changes and issues which destabilize contemporary $\mathrm{BiH}$ family is characteristic of $\mathrm{BiH}$ society. Thus, $\mathrm{BiH}$ family and its members should be offered necessary (institutional, formal and informal, government or non-government) support in this process of intensive changes and facing many challenges.

\section{Conclusion}

Family investigation and study field has long considered the issue of family issues with particular attention to how families cope with stress related to various life transitions (becoming parents, having children 
of different age (going to primary/high school, university, empty nest syndrome, inability to conceive etc) and difficult life events (war, losses, physical and psychological traumas). Life of contemporary man is marked by many internal and external challenges which impact his performance within family and society in general.

Current family is "diverse "postmodern" family which is fluid and distinct from previous generations, essentially broadening the scope of family problems definition, as well as expert interpretation of the challenges families face in their everyday lives and how best to solve these challenges" (Arditti, 2015, p. 3.). Bosnian family faces many general (societal) (transition of $\mathrm{BiH}$ society, family transition) as well as personal/psychological challenges. Considering that family and society are intertwined (i.e. family constitutes society), aforementioned challenges influence and impact family in a very complex way, whereas it is almost impossible to distinguish which starts and ends where. This makes $\mathrm{BiH}$ family life and existence more complex and difficult indicating necessity of systematic help and assistance, institutionally and professionally, simultaneously.

It also has to be noted that, just like society transition, family transformation cannot be stopped, which means, this process should be properly supported instead. Numerous changes in $\mathrm{BiH}$ society destabilize contemporary family because family members and family system are exposed to continuous influences of social and intrafamilial changes which are unstoppable and necessary. Thus, $\mathrm{BiH}$ family and society will continue its transformation and transition and their custodians in this process face severe changes and encounter many personal and general challenges.

\section{References}

Alić, A. (2008). Relacije između obiteljskih odnosa i preferiranje vrijednosnih orijenatacija. Zbornik radova nastavnika Pedagoškog Fakulteta, Faculty of Pedagogy, Zenica, No. 6.

Amato, P. R., \& Previti, D. (2003). People's reasons for divorcing: Gender, social class, the life course, and adjustment. Journal of Family Issues, 24(5), 602-626.

Arditti, J., A., (ed.), (2015). Family problems: Stress, risk and resilience. Wiley Blackwell, UK. 
Babović, M., Pavlović O., Ginić K., Karađinović N., (2013). Rasprostranjenost $i$ karakteristike nasilja nad ženama $u$ BiH. Sarajevo, Agencija za ravnopravnost spolova $\mathrm{BiH}$.

Beridan I. (1997). Porodica $i$ rat: Socijalne funkcije porodice u ratu. Unpublished doctoral dissertation. University of Sarajevo, Faculty of Political Sciences, Sarajevo.

Čudina-Obradovic M., Obradovic, J. (2006). Psihologija braka i obitelji. Golden marketing, Tehnicka knjiga, Zagreb.

Dizdarevic, I., (1978). "Socijalno-psihološke osnove uticaja mladih u procesu transformacije porodice." Pregled, No. 3.

Dizdarević I., (2002). Agenti socijalizacije ličnosti. Prosvjetni list, Sarajevo.

Draganovic, S., (2015). Psihosocijalne determinante razvoda braka. Unpublished doctoral dissertation. University of Sarajevo. Department of Psychology, Sarajevo.

Dwivedi K. N., i Harper P. B., (2004). Promoting the emotional Well-being of children and Adolescents and preventing their ill mental health. Jessica Kingsley Publishers, London.

Habul U., (2000). Institut razvoda braka u savremenim uslovima sa posebnim osvrtom na domace pravo. Unpublished doctoral dissertation. University of Sarajevo, Law Faculty.

Haveric Z., (2000) Trauma i obiteljski odnosi (unpublished work), Faculty of Philosophy, Department of Psychology, Sarajevo.

Holt-Lunstad, J., Smith, T. B., \& Layton, J. B. (2010). "Social relationships and mortality risk: A meta-analytic review.” PLoS Medicine, 7(7).

Hughes, M., Kroehler C. J., (2012). Sociology: The core. McGraw-Hill Education, New York.

Isanovic A., (2006). Media discourse as a male domain: Gender representation in the daily Newspaper in BiH, Croatia and Serbia. In Moranjak Bamburic N., Jusic T., Isanovic A., (Eds). Stereotyping: representation of women in print media in Southeast Europe (pp. 43-81), Media Center, Sarajevo.

Jordanova K., (2012). "Transmission of traumatic experiences in the families of war survivors from Bosnia and Herzegovina." Suvremene Teme, 5. No. 1.

Kosovic (1987), "no title." In Latic A., and Murtic R. (2013). Funkcionalnost porodice sa aspekta sistemske porodicne terapije- Iskustvo KJU «Porodicno Savjetovalište», (taken from http://www.porodicno.ba, 15.01.2013).

Kuburic, Z., (2001). "Muskarac i zena u religiji i realnom zivotu." In B., Jovanovic, (Eds.). Muskarac i zena. Gutenbergova galaksija, Beograd. 
Letić N., Ivanović B., (2012). Istraživanje o iskustvima mladih u Bosni $i$ Hercegovini vezanim za različite oblike nasilja i trauma u djetinjstvu. Banjaluka, Kinderpostzegels i IN fondacija.

Marsh, I., and Keating, M., (2006). Sociology: Making sense of society. New Jersey, Prentice Hall.

Olds, J., Schwartz, R. (2010). The lonely American: Drifting apart in the twentyfirst century. Boston, MA: Beacon Press.

Pašalić-Kreso, A., (2004). Koordinate obiteljskog odgoja, Jež, Sarajevo.

Pejanovic M. (2005). Politicki razvitak BiH u postdejtonskom periodu. TDK, Šahinpašic, Sarajevo.

Silajdzić A., (1973). Razvojne tendencije naše porodice. Svjetlost, Sarajevo

Sedrakyan, S., (2014). Family psychology. Las Vegas, USA.

Silva E., Smart C. (1999). The new family. London, SAGE publications Ltd.

Van Every, J. (1999). "From modern nuclear family households to postmodern diversity: The sociological construction of families." In G. Jagger and C. Wright (eds.) (1999). Changing family values. Psychology Press, Routledge, London.

Žiga J. (2013). Porodica u Bosanskohercegovackom društvu sa posebnim osvrtom na stanje u Kantonu Sarajevo, taken from website "Porodicno Savjetovalište" (8. 10. 2013.). 